\title{
An Assessment of Impact of Income Inequality on Sustainable Economic Growth in the Context of Saving
}

\author{
Remigijus Ciegis $^{1}$, Aidas Dilius² ${ }^{2}$ Karolis Andriuskevicius ${ }^{1}$ \\ ${ }^{1}$ Vilnius University \\ Muitines st. 8, LT-44280, Kaunas, Lithuania \\ E-mail.remigijus.ciegis@khf.vu.lt; karolis.andriuskevicius@gmail.com \\ ${ }^{2}$ Sauliai University \\ P. Visinskio st. 19, 77156, Siauliai, Lithuania \\ E-mail.aidasdilius@gmail.com
}

cross $^{\text {ref }}$ http://dx.doi.org/10.5755/j01.ee.28.3.17438

Income inequality projects a different impact on economic growth as it can both stimulate and slow down economic growth. The stimulating effect of income inequality is revealed via saving. Specifically, wealthy social classes dispose the capability to save more and devote a larger portion of their saving to investments and technological developments. However, environmental and social perspectives shall be taken into consideration when aiming for a sustainable development. This paper considers the effects of income inequality on sustainable economic growth in the context of saving for the EU-25 countries during the period of 2005-2013. The empirical research of this study is done using open code software package Gretl and working with panel data. Based on the relationship between income inequality ratio, economic growth and GDP per capita, countries have been divided into 4 clusters. Empirical results support impact of reciprocal action among income inequality, savings, economic growth, spending on social security to domestic material consumption, renewable energy in gross final energy consumption, municipal waste generation, municipal waste recycling, ammonia and greenhouse gas emissions to be insignificant in all four country cluster groups. Reciprocal action among income inequality, savings, economic growth, and spending on social security was estimated to increase emission of sulfur dioxides and nitrogen oxides, but reduced the amount of gross domestic energy consumption. The reciprocal action is estimated to increase emission of nitrogen oxides in the country cluster groups with relatively low income level and different relationship between income and economic growth levels.

Keywords: Income Inequality, Sustainable Development, Saving, Economic Growth, Environmental Dimension.

\section{Introduction}

Increase of income inequality determines micro- and macro level social economic consequences. Impact of sustainable economic growth is one of the consequences of increasing income inequality. Effects of income inequality on the sustainable economic growth can be measured by evaluating effects of income inequality on factors which affect economic growth, social and environmental areas.

Effects of income inequality on economic growth are controversial meaning that income inequality effects can be both stimulating and slowing down the total economic growth. Stimulating influence appears via saving as increasing inequality leads to increasing saving of wealthy social class (increasing saving circumstances increasing investments). However, environmental effects are mixed. If wealthy social class considers environmental areas and redistribute their resources into investments and technological developments, then increasing income inequality can lead to economic growth and improve environmental conditions. Even though income inequality can stimulate economic growth and improve environmental conditions, the poorest social class and spending on social security cannot be ignored.

Therefore, income inequality and saving rate shall be sought in such a way which stimulates economic growth and considers the poorest class of society and the environmental conditions. However, there is a clear gap in the existing literature and the empirical research of studies which analyse the impact of income inequality on sustainable economic growth in the context of saving. In addition to the dynamics of income inequality, a level of income inequality shall be considered when assessing the impact of income inequality on economic growth. It is hypothesized that it depends on the level of income inequality whether the increasing income inequality leads to stimulating or slowing down effects of economic growth. However, findings of the existing literature support that the impact of income inequality depends not only on the level of income inequality, but also on the income level of a particular country.

This article analyses impact of income inequality on sustainable development from the perspective of saving rate. In other words, it elaborates on the reciprocal action between income inequality, savings, economic growth, spending on social security and factors of environmental area. Overall, this paper considers effects of economic and social areas on environment.

The purpose of the article is twofold. Firstly, it is sought to present theoretical interpretations and framework for the assessment of impact of income inequality on sustainable economic growth in the context of saving. 
Secondly, an empirical study for the case of EU-25 countries is performed based on the theoretical framework.

The tasks of the research are:

1. To discuss effects of income inequality on sustainable development in the context of saving and provide theoretical interpretations;

2. To provide an evaluation of the effects of income inequality on sustainable development in the context of saving for the EU-25 countries.

Research is performed through the employment of panel data and division of countries into four clusters. Three sections constitute the article. The first section presents theoretical framework. The second section elaborates on the methodology of empirical analysis. The third section presents results of the empirical analysis for the case of EU25 countries during the period of 2005-2013.

\section{Theoretical Background}

Impact of income inequality on economic growth is controversial. In other words, income inequality can both stimulate and impede economic growth (Sbaouelgi, Boulila, 2016; Brueckner, Lederman; 2015; Carvalho, Rezai, 2015; Charles-Coll, 2012). Consideration of sustainable economic growth puts another dimension into the assessment of income inequality on economic growth. Therefore, further section continues with theoretical foundation of assessment of income inequality on economic growth. Theoretical part of the article starts with an assessment of impact of income inequality on economic growth from a saving aspect. Afterwards assessment of impact of income inequality on sustainable economic growth from a saving aspect continues the theoretical background.

An assessment of income inequality on economic growth can be performed from various aspects. One of the relevant aspects is saving (Grundler \& Scheuermeyer, 2014; Malinen, 2009; Barro, 2000). An assessment of impact of income inequality on economic growth from a saving aspect is being done while making an assumption that impact is stimulating economic growth. In other words, income of the most wealthy society class increases together with an increasing level of income inequality. Increase of the income allows the most wealthy society class to devote larger part of their resources to investments and R\&D. Increasing investments and technological developments lead to economic growth (Barro, 2000).

Even though income inequality may impose a stimulating impact on economic growth, but economic growth may worsen environmental conditions (Lopez, 1994; Grossman, Krueger, 1991). Environmental area is attributed to the definition of sustainable development. The definition of sustainable development relates three key dimensions: economic, environmental and social development. These three dimensions are identified as interrelated and mutually supportive (Ciegis, Ramanauskiene, Martinkus, 2009). Therefore sustainable economic growth must be taken into consideration when assessing effects of income inequality on economic growth. In other words, an economic growth which harmonizes economic, social and environmental fields shall be sought when pursuing economic growth (Ciegis \&
Ramanauskiene, 2011). Mixed effects of income inequality on economic growth depend on saving levels of higher society class, quantity and scope of investments, corporate expenses to $R \& D$. Therefore, impact of income inequality on economic growth from a saving aspect is further analysed.

As mentioned earlier, an assumption is being made that income inequality from a saving aspect composes a stimulating effect on economic growth. However, S. Ryoo (2013) and P. Bofinger (2012) propose that increase of income inequality reduces saving level of households whose income is being reduced more than these households would be willing to consume. Accordingly to S. Ryoo (2013), increase of income inequality leads to higher borrowing levels of poor households. As discussed by S. Ryoo (2013) and P. Bofinger (2012), increase of income inequality leads to increase of saving rates of wealthier households and to decrease of saving rates of poorer households. Since it remains unknown whether effects of increased saving level of wealthier households or decreased saving level of poorer households are larger, an overall country saving level shall be taken into consideration.

Increase of saving level might be needed for two key reasons. Firstly, increase of saving level is a prerequisite to seek and experience larger investments, technological developments and economic growth. In line with J. M. Keynes (1937), increase of marginal saving rate leads to decreased marginal consumption rate. Consumption of wealthier households may worsen environmental conditions. Therefore, consumption of wealthier households is called environmental inequality (Policardo, 2015). As discussed by Policardo (2015), income inequality stimulates environmental inequality indirectly, i.e. trough impact to factors that increase environmental damage.

Secondly, as mentioned earlier, higher saving level may be essential to increase investment levels and technological expansion while seeking economic growth. Accordingly to Rezai, S. Stagl (2016) and A. Berthe, L. Elie (2015), improvement of environmental conditions can be received through increases in saving level and investment to technological developments. Subsequently, increase of income inequality may lead to reduced pollution emission (Ali, Hassan, Kofarmata, 2016).

A. Berthe, L. Elie (2015), L. Taylor, A. Rezai, D. K. Foley (2015) and L. A. Scruggs (1998) determines slowing down effects of income inequality on economic growth. Authors provide two different insights into reasons behind slowing down effects of income inequality on economic growth and mixed effects on environmental conditions. Firstly, on the one hand increased level of income inequality means increased saving level. On the other hand, as number of poor households increases, increased level of income inequality associates with reduced consumption leve. Subsequently, increased marginal saving rate may slow down economic growth, but will save environmental resources. Similarly, L. Taylor, A. Rezai, D. K. Foley (2015) and X. Gu, B. Dong, B. Huang (2014) contemplate that increased saving rate might not definitely lead to increased investment level. Therefore, increased saving level, reduced investment level and reduced consumption level are slowing down economic growth. 
Secondly, increased level of income inequality may reduce number of consumers whose habits include purchases of environmental- and consumption-friendly goods and services. Accordingly to L. Taylor, A. Rezai and D. K. Foley (2015), manufacturing of environmental- and consumption-friendly goods and services reduce pollution emission. Subsequently, economic growth is stimulated and opportunities to improve environmental conditions are increased. However, controversial relationship between income inequality and technological developments remains. For instance, F. Vona and F. Patriarca (2011) identify that increased level of income inequality slows down technological developments which are needed to manufacture environment friendly goods and services.

Based on studies and insights provided above, it is being hypothesized that from the consumption perspective increased level of income inequality reduces consumption level (social area), slow down economic growth (economic area) and do not improve environmental area as it reduces consumption of environment- and consumption- friendly goods and services (environment area). Therefore, reduced income inequality shall be sought. From the perspective of saving, increased level of income inequality increase corporate saving level, investments and $R \& D$ expenses. Investments and technological developments stimulate economic growth and may improve environmental conditions if sufficient corporate resources are devoted to environmental protection. However, social area shall also be taken into consideration.

Overall, as discussed earlier, not only effects of income inequality on economic growth and environmental area, but also impact of income inequality on social area shall be taken into consideration. As discussed in studies by A. Berthe, L. Elie (2015), F. Vona, F. Patriarca (2010), L. Kuijs, T. Wang (2006), L. A. Scruggs (1998), sustainable economic developments shall be sought by governments trough implementation of fiscal policies. Through consideration of income inequality and social area, governments may increase spending on social security while seeking increased human capital.

Economic growth is stimulated by increased physical capital (Rezai, Stagl, 2016; Arjona, Ladaique, Pearson, 2003) and employment of human capital. Several authors (Arjona, Ladaique, Pearson, 2003) suggest that increased level of human capital stimulates higher rate of utilization of physical capital.

Therefore, R. Arjona, M. Ladaique and M. Pearson (2003) have raised three questions when assessing impact of income inequality on economic growth. Firstly, what is the impact of income inequality on economic growth? Secondly, what is the impact of social security spending on economic growth? Thirdly, what is the relationship between income inequality and social security spending?

Income redistribution reduces the level of income inequality, but impact on economic growth remains controversial. Increased government spending on social security may circumstance both: increased economic growth (Charles-Coll, 2012; Arjona, Ladaique, Pearson, 2003) and decreased economic growth (Arjona, Ladaique, Pearson, 2003). S. Mahendra Dev (2016) supports that policy of income redistribution reduces level of income inequality, saving level, investment volume and economic growth. It is being suggested (Mahendra Dev, 2016) that education level shall be increased while redistributing income between households in order to stimulate economic growth.

K. Schmidt-Hebbel, L. Serven (2000) supports that impact of income inequality on total saving level is controversial. Subsequently, only empirical research may help to distinguish, whether income inequality increase or decrease total saving level. For instance, in case of increasing level of income inequality, the policy of income redistribution may not only reduce level of income inequality, but it also may reduce saving level, investment volume and economic growth. In other words, increased taxes may reduce income of households which dispose relative higher level of income. L. Sineviciene and A. Vasiliauskaite (2012) note scientific literature supporting that increase of investments reduces economic growth. However, there is a gap of scientific findings on the reciprocal action between fiscal policy and investments.

L. A. Scruggs (1998) finds that impact of income inequality on environmental conditions depends on damage to environmental conditions and households' income level. In other words, income level may increase faster than damage to the environment. Moreover, increase of income level can be the same level as damage to the environment or increase slower than damage to the environment. However, two problems arise in this case. Firstly, technologies are essentially needed in order for the income level to increase quicker than damage to environment. Secondly, despite the fact that damage to the environment increase slower than income level, this increase can be unfair from the perspective of sustainable development as absorption capabilities of the environment are unknown. This infers that any increase of environmental damage does not lead to sustainable developments. Therefore, an economic growth which minimizes environmental damage shall be sought.

P. Bofinger and P. Scheuermeyer (2016) assert that relationship between income inequality and saving rate as well between income inequality and economic growth may be subject to level of income inequality. Therefore, without empirical research it remains unknown how does income inequality affect sustainable economic growth.

Overall, increasing and decreasing level of income inequality may impact economic growth and environmental conditions indeterminate. The impact is subject to numerous additional factors. Income inequality may increase saving level, investment volume and technological developments. However, investments into environment friendly technologies and spending on social security shall be stimulated considering economic, social and environmental areas. This way, once economic growth period is experienced, improvements of environmental conditions may be sought while income redistribution policy would reduce level of income inequality and slow down economic growth simultaneously. Since total income equality cannot be reached and overall is not desirable, it shall be sought that income inequality would impact economic growth in such a way that economy would move towards sustainable growth. Assessment of income inequality on economic growth from aspect of saving will be performed further. Research design is presented beforehand. 


\section{Research Design}

This article analyses impact of income inequality on economic growth from the savings aspect in EU-25 countries during the period of 2005-2013. Research is done using open code software package Gretl which is assigned to work with panel data. Countries are divided into 4 clusters.

First cluster includes countries which had negative relationship between income inequality ratio and economic growth and had less than 20000 euros of GDP per capita. Following countries belong to the first cluster: Latvia, Poland, Lithuania, Hungary, Estonia and Slovakia.

The second cluster includes countries which had negative relationship between income inequality ratio and economic growth and had more than 20000 euros of GDP per capita. Following countries belong to the second cluster: Portugal, Czech Republic, Slovenia, Greece, Cyprus, Spain, Italy, Belgium and The Netherlands.

The third cluster includes countries which had positive relationship between income inequality ratio and economic growth and had less than 29500 euros of GDP per capita, while the fourth cluster had more than 29500 euros of GDP per capita. Following countries belong to the third cluster: France, United Kingdom and Finland. Following six countries belong to the fourth cluster: Denmark, Sweden, Austria, Ireland and Luxembourg (Ciegis, Dilius, 2015).

Indicators and variables of the empirical research are chosen considering impact of income inequality on sustainable economic growth in the context of saving. Variables consider three key aspects in economic theory: efficiency, propriety and sustainability (Ciegis et al., 2009). To sum it all up, chosen variables gauge social state, economic developments and environmental state (Kilijoniene et al., 2010).

Empirical part of the article analyses impact of reciprocal action between four independent variables (Gini coefficient, saving rate, real GDP per capita and social protection benefits per capita) on the environmental area. Since environmental area is represented by ten variables of environmental area, ten models (equations) using OLS methodology are created. OLS methodology is employed because it applies to short term time series. An alternative method to examine short term time series would be incorporating the Arellano-Bond model. However, our research limits itself with OLS methodology as this is economics' rather than econometrics' paper. Third cluster will be used as a basis in the first nine models whereas the second cluster will be used as a basis in the tenth model. An equation where the third cluster is used as a basis is presented below:

$\Delta \ln \left(\right.$ Env_dim $\left._{\mathrm{i}, \mathrm{t}}\right)=\alpha+\operatorname{td}_{3} 2007+\ldots+\operatorname{td}_{9} 2013+$

$+\beta_{1} \Delta \ln \left(\right.$ Gini $_{\mathrm{i}, \mathrm{t}} \cdot \Delta \ln \left(\right.$ Saving $\left._{\mathrm{i}, \mathrm{t}}\right) \cdot \Delta \ln \left(\right.$ gdp $\left._{\mathrm{i}, \mathrm{t}}\right) \cdot \Delta \ln \left(\right.$ Soc_prot $\left._{\mathrm{i}, \mathrm{t}}\right)$

$+\beta_{2} \Delta \ln \left(\operatorname{Gini}_{\mathrm{i}, \mathrm{t}}\right) \cdot \Delta \ln \left(\operatorname{Saving}_{\mathrm{i}, \mathrm{t}}\right) \cdot \Delta \ln \left(\mathrm{gdp}_{\mathrm{i}, \mathrm{t}}\right) \cdot \Delta \ln \left(\operatorname{Soc}_{\sin } \operatorname{prot}_{\mathrm{i}, \mathrm{t}}\right) \cdot \mathrm{I} \_\mathrm{c}$

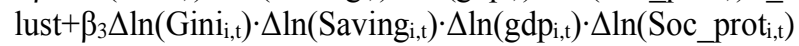
-II_clust $+\beta_{4} \Delta \ln \left(\right.$ Gini $\left._{i, t}\right) \cdot \Delta \ln \left(\right.$ Saving $\left._{\mathrm{i}, \mathrm{t}}\right) \cdot \Delta \ln \left(\right.$ gdp $\left._{\mathrm{i}, \mathrm{t}}\right) \cdot \Delta \ln \left(\right.$ Soc_p $_{\mathrm{i}}$ $\left.\operatorname{rot}_{\mathrm{i}, \mathrm{t}}\right) \cdot \mathrm{IV}$ _clust $+\mathrm{c}_{1} \Delta \ln \left(\mathrm{Educ}_{\mathrm{i}}\right.$ tert $\left.\mathrm{i}_{\mathrm{i}, \mathrm{t}}\right)+\mathrm{c}_{2} \Delta \ln \left(\mathrm{Gov}_{\mathrm{i}, \mathrm{t}}\right)+\mathrm{c}_{3} \Delta \ln \left(\mathrm{PI}_{\mathrm{i}, \mathrm{t}}\right.$ )$\left.+\mathrm{c}_{4} \Delta \ln \overline{(\text { Life_exp }} \mathrm{i}_{\mathrm{t}, \mathrm{t}}\right)+\mathrm{c}_{5} \Delta \ln \left(\right.$ Export $\left._{\mathrm{i}, \mathrm{t}}\right)+\mathrm{u}_{\mathrm{i}, \mathrm{t}}$

where Env_dim ${ }_{i, t}-$ dependent variables of Environmental dimension in country $i$ and year $t ; \alpha-$ is constant; $t d_{t}$ - time dummies; $\beta$ - coefficients reflecting impact of independent variable on dependent variable;
Gini $_{i, t}$ - Gini coefficient of equivalent disposable income in country $i$ and year $t$; Saving sit $_{\text {- saving rate in country } i \text { and }}$ year $t$; $g d p_{i, t}$ - real GDP per capita (in PPS) in country $i$ and year $t$; Soc_prot ${ }_{i, t}$ - Social protection benefits per capita (in PPS) in country $i$ and year $t$; $u_{i, t}$ - error terms.

Control variables: Educ_tert $t_{i, t}$ - tertiary education (population by educational attainment level (percentage, from 15 to 64 years)) in country $i$ and year $t$; Govi,tgovernment final consumption expenditure, real expenditure per capita (in PPS) in country $i$ and year $t ; P I_{i, t}$ - price index (implicit deflator), 2010 $=100$, euro in country $i$ and year $t$; Life_exp $p_{i, t}$ - life expectancy (year) in country $i$ and year $t$; Export $_{i, t}-$ exports of goods and services (chain linked volumes (2010), million euro) in country $i$ and year $t$.

Environment variables: Domestic material consumption (tones per capita) (Material_cons); Share of renewable energy in gross final energy consumption (percentage) (Renew_energy); Municipal waste generated (kilograms per capita) (Municipal); Total waste treatment (kilograms per capita) (Waste_treat); Sulphur oxides (tons) (Sulphur); Nitrogen oxides (tons) (Nitrogen); Ammonia (tons) (Ammonia); Non-methane volatile organic compounds (tons) (Volatile); Greenhouse gas emissions (CO2 equivalent, thousand tons) (Greenhouse_gas); Energy (Gross inland consumption (thousand tons of oil equivalent)) (Energy).

All variables used in equations are logarithmic and have been differentiated. Therefore, results of the performed econometric analysis are presented as elasticity coefficients. Furthermore, heteroscedacity, autocorrelation and multicolinearity are being checked. It was checked for heteroscedacity in the econometric model using White's test. Heteroscedacity has been found to prevail. Therefore, model estimates have been calculated using robust (HAC) standard errors. Based on the research design, empirical research is presented further.

As discussed earlier, the empirical research is performed using four independent variables and estimating the effects of their reciprocal action to environmental conditions. Gini coefficient and spending on social security represent social sphere, while saving rate and economic growth represent economic sphere. Composed econometric models reflect neither the impact of economic sphere to social sphere nor the impact of social sphere to economic sphere.

Since there are ten variables attributed to the environmental area, in the assessment of impact of economic and social areas on the environmental area, ten models are developed.

\section{Research Results}

This part of the article presents research results of assessment of impact of reciprocal action among income inequality, saving, economic growth and spending on social security and environmental areas. In other words, an assessment of the relationship among identified reciprocal action and ten variables of environmental area is performed. The third cluster is chosen in the assessment of reciprocal action among income inequality, saving, economic growth and spending on social security and the first nine variables of environmental area. 
Table 1

Reciprocal Action Between Gini Index, Saving Rate, Real GDP Per Capita, Social Protection and Environmental Dimensions

\begin{tabular}{|c|c|c|c|c|}
\hline Dependent variables & \multicolumn{4}{|c|}{ Independent variables } \\
\hline Env_dim & $\begin{array}{c}\text { Gini*Saving*gdp* } \\
\text { *Soc_prot }\end{array}$ & $\begin{array}{c}\text { Gini*Saving*gdp* } \\
\text { *Soc_prot*Icluster }\end{array}$ & $\begin{array}{c}\text { Gini*Saving*gdp* } \\
\text { *Soc_prot*IIcluster }\end{array}$ & $\begin{array}{c}\text { Gini*Saving*gdp* } \\
\text { *Soc_prot*IVcluster }\end{array}$ \\
\hline Material_cons & $-59,130$ & $-53,596$ & $-1148,510$ & $-498,636$ \\
\hline Renew_energy & 717,120 & $-762,306$ & $-879,958$ & $-1936,82$ \\
\hline Municipal & 486,332 & $-622,382$ & $-216,463$ & $-857,026$ \\
\hline Waste_treat & 1111,400 & $-1487,550$ & $-1226,52$ & $-1832,890$ \\
\hline Sulphur & $\mathbf{5 2 7 4 , 4 9 0 * * *}$ & $-\mathbf{4 9 4 3 , 6 4 0 * * *}$ & $\mathbf{- 5 1 3 3 , 4 6 0 * *}$ & $-\mathbf{7 5 5 3 , 3 7 0 * *}$ \\
\hline Nitrogen & $\mathbf{2 4 1 9 , 0 5 0 * * *}$ & $\mathbf{- 2 3 5 2 , 4 6 0 * * *}$ & $-\mathbf{3 5 4 8 , 5 0 0 * * *}$ & $-\mathbf{4 7 3 2 , 7 0 0 * * *}$ \\
\hline Ammonia & $-119,039$ & 126,503 & 843,750 & $-138,896$ \\
\hline Volatile & $\mathbf{1 5 6 2 , 3 3 0 * * *}$ & $-\mathbf{1 5 4 1 , 1 3 0 * * *}$ & $-860,233$ & $-1615,510$ \\
\hline Greenhouse_gas & 116,066 & $-153,572$ & $-409,691$ & $-402,069$ \\
\hline
\end{tabular}

* - sig. level $90 \%$, ** - sig. level $95 \%$, *** - sig. level $99 \%$

Source: performed by authors using Statistical Office of the European Union Eurostat data (2015)

Results of empirical research presented in Table 1 support effects of reciprocal action among income inequality, saving, economic growth and social security spending to domestic material consumption, the share of renewable energy in final energy consumption, municipal waste generation, municipal waste recycling, ammonia and greenhouse gas emissions is insignificant.

However, effects of reciprocal action among income inequalities, saving, economic growth and social security spending to sulfur dioxide, nitrogen oxides and volatile organic compounds without methane are found to be direct and significant. In other words, reciprocal action among income inequality, saving, economic growth and social security spending may have increased level of emissions of sulfur dioxide, nitrogen oxides and volatile organic compounds without methane in all four cluster groups. Positive estimates in the values of 5274,490 and 1562,330 supports respectively stimulating impact of sulfur dioxide and volatile organic compounds without methane in the basic cluster group. Effects of reciprocal action in the first cluster group were smaller, the respective values were 4943,640 and -1541,130. Difference of effects of reciprocal action between income inequality, saving, economic growth and social security spending to sulfur dioxide in the fourth cluster group was found to be larger than in the basic cluster group, i.e. the estimate found is -
7553,370 . However, hypothesis that difference in impact is insignificant has been approved, because $p>0,05$. To sum it all up, stimulating impact of the reciprocal action among income inequality, saving, economic growth and social security spending to sulfur dioxide, nitrogen oxides and volatile organic compounds without methane is found in all cluster groups (see Table 1).

Stimulating impact of reciprocal action among income inequality, saving, economic growth and social security spending to nitrogen oxides was identified only for the basic and first cluster groups; the respective values are 2419,050 and $-2352,460$. However, reverse reciprocal action among income inequality, saving, economic growth and social security spending to nitrogen oxides was identified for the second and fourth clusters (estimates respectively being $-3548,500$ and $-4732,700$ (see Table $1)$ ). In other words, reciprocal action between income inequality, saving, economic growth and social security spending could have reduced emission of nitrogen oxides in cluster groups with high income level, but different impact of economic inequality to economic growth.

Second country cluster group was chosen in the assessment of impact between reciprocal action of income inequality, saving, economic growth and social security and the tenth variable of environmental area (energy consumption).

Table 2

Reciprocal Action Between Gini, Saving Rate, Real GDP Per Capita, Social Protection and Energy Consumption

\begin{tabular}{|c|c|c|c|c|}
\hline \multirow{2}{*}{$\begin{array}{l}\text { Dependent } \\
\text { variables }\end{array}$} & \multicolumn{4}{|c|}{ Independent variables } \\
\hline & $\begin{array}{l}\text { Gini*Saving*gdp* } \\
\text { *Soc_prot }\end{array}$ & $\begin{array}{l}\text { Gini*Saving*gdp* } \\
\text { *Soc_prot*Icluster }\end{array}$ & $\begin{array}{l}\text { Gini*Saving*gdp* } \\
\text { *Soc_prot*IIIcluster }\end{array}$ & $\begin{array}{l}\text { Gini*Saving*gdp* } \\
* \text { Soc_prot*IVcluster }\end{array}$ \\
\hline Energy & $-830,512 * * *$ & $872,888 * * *$ & $1058,490 * * *$ & $695,163 * * *$ \\
\hline
\end{tabular}

* - sig. level $90 \%$, ** - sig. level $95 \%$, *** - sig. level $99 \%$

Source: performed by authors using Statistical Office of the European Union Eurostat data (2015)

Results of empirical research presented in Table 2 show that negative estimate value of $-830,512$ is calculated in the basic cluster group which estimates relationship between reciprocal action of Gini coefficient, saving rate, GDP per capita and spending on social security, and gross domestic energy consumption. However, no differences of assessment impact are found in the first, third and fourth country cluster groups. In other words, hypothesis that no differences of assessment impact is accepted for the first and third country cluster groups, because $p>0,05$. Estimate of relationship among reciprocal action of Gini coefficient, saving rate, GDP per capita and spending on social security, and gross domestic energy consumption in the fourth country cluster is found lower than in the basic 
cluster group. Therefore, it can be summarized that reciprocal action of Gini coefficient, saving rate, GDP per capita and spending on social security reduced gross domestic energy consumption in all four country cluster groups.

To sum it all up, based on results of empirical research it is being summarized that reciprocal action among income inequality, savings, economic growth, spending on social security have increased emissions of sulfur dioxide and nitrogen oxides, but reduced gross domestic energy consumption in all four country cluster groups. However, reciprocal action between income inequality, savings, economic growth, spending on social security may have increased emission of nitrogen oxides for the first and third country cluster groups, but reduced emission of nitrogen. oxides in the second and fourth country cluster groups. In other words, the reciprocal action increase emission of nitrogen oxides in the country cluster groups with relatively low income level and different relationship between income and economic growth levels. Accordingly, the reciprocal action is found to reduce emission of nitrogen oxides in the country cluster groups with relatively high income level and different relationship between income inequality and economic growth.

\section{Conclusions}

To sum up the theoretical part, it is ascertained that impact of income inequality on sustainable economic growth is controversial. Income inequality may stimulate and slow down economic growth. Income inequality stimulates economic growth as wealthy social class can save, devote larger funds to investments and technological developments. From environmental point of view, funds can be allocated to investments and technological developments in ways which save natural resources and reduce pollution levels. Social area shall be considered as a prerequisite for income inequality to stimulate economic growth. Therefore, spending on social security is important to be adequately considered.

To sum up the empirical part, it is ascertained that mixed impact among reciprocal action of variables of economic and social areas, i.e. reciprocal action between income inequality, savings, economic growth, spending on social security and factors of environmental area, was found in the research. Impact of reciprocal action between income inequality, savings, economic growth, spending on social security to domestic material consumption, renewable energy in gross final energy consumption, municipal waste generation, municipal waste recycling, ammonia and greenhouse gas emissions was estimated to be insignificant in all four country cluster groups. Reciprocal action among income inequality, savings, economic growth, spending on social security was estimated to increase emission of sulfur dioxides and nitrogen oxides, but reduced amount of gross domestic energy consumption.

Direct impact of reciprocal action among income inequality, savings, economic growth, spending on social security to emission of nitrogen oxides was found only for the first and third country cluster groups. In other words, reciprocal action increase emission of nitrogen oxides in the country cluster groups with relatively low income level and different relationship between income and economic growth levels. Accordingly, reciprocal action is found to reduce emission of nitrogen oxides in the country cluster groups with relatively high income level and different relationship between income inequality and economic growth.

Since pollution in the group of relatively wealthy country cluster group was found to be reduced when level of income inequality increased, it is concluded that relatively wealthy social class save more, allocate more resources to environmental improvement and income redistribution when pursuing economic growth and increasing income of lower social class.

\section{References}

Ali, H. S., Hassan S., \& Kofarmata, Y. I. (2016). Dynamic Impact of Income Inequality on Carbon Dioxide Emissions in Africa: New Evidence from Heterogeneous Panel Data Analysis. International Journal of Energy Economics and Policy, 6(4), 760-766. Available from internet http://www.econjournals.com/index.php/ije ep/article/view/ $3193 / 2211$

Arjona, R., Ladaique, M., \& Pearson, M. (2003). Growth, Inequality and Social Protection. Canadian Public PolicyAnalyse De Politiques (OECD), p. 119-139. Available from internet: http:/www.csls.ca/cpp/2/Arjona.pdf., https://doi.org/10.2307/3552279

Barro, R. J. (2000). Inequality and growth in a panel of countries. Journal of Economic Growth, 5(1), 5-32. https://doi.org/10.1023/A:1009850119329

Berthe, A., \& Elie, L. (2015). Mechanisms explaining the impact of economic inequality on environmental deterioration. Ecological Economics, 116, 191-200. https://doi.org/10.1016/j.ecolecon.2015.04.026

Bofinger, P. (2012). The Impact of Inequality on Macroeconomic Dynamics. Universitat Wurzburg and German Council of Economic Experts, p. 1-14. Available from internet: https://www.ineteconomics.org/uploads/papers/bofingerpeter-berlin-paper.pdf.

Brueckner, M., \& Lederman, D. (2015). Effects of Income Inequality on Aggregate Output. Policy Research Working Paper, 7317, p. 1-32. Available from internet: http://documents.worldbank.org/curated/en/2911514681886 58453/pdf/WPS7317.pdf. https://doi.org/10.1596/1813-9450-7317 
Carvalho, L., \& Rezai, A. (2015). Personal income inequality and aggregate demand. Cambridge Journal of Economics, 40(2), 1-15.

Charles-Coll, J. A. (2012). The optimal rate of inequality: a framework for the relationship between income inequality and economic growth. Global Thematic Consultation, p. 1-19. Available from internet: https://mpra.ub.unimuenchen.de/28921/1/MPRA_paper_28921.pdf.

Ciegis, R., \& Dilius, A. (2015). Pajamu nelygybes poveikio darniam ekonomikos augimui vertinimas // Darnaus vystymosi problemos ir jų sprendimai Lietuvoje. - Vilniaus universitetas, Aleksandro Stulginskio universitetas, p. 9-50.

Ciegis, R., \& Ramanauskiene, J. (2011). Integruotas darnaus vystymosi vertinimas: Lietuvos atvejis // Management theory and studies for rural business and infrastructure development, Nr. 2 (26), p. 1-12. Available from internet: http://vadyba.asu.lt/26/39.pdf.

Ciegis, R., Ramanauskiene, J., \& Martinkus, B. (2009). The Concept of Sustainable Development and its Use for Sustainability Scenarios. Inzinerine Ekonomika-Engineering Economics (2), 28-37

Ciegis, R., Ramanauskiene, J., \& Startiene, G. (2009). Theoretical Reasoning of the Use of Indicators and Indices for Sustainable Development Assessment. Inzinerine Ekonomika-Engineering Economics (3), 33-40.

Grossman, G. M., \& Krueger, A. B. (1991). Environmental Impacts of a North American Free Trade Agreement. NBER Working Papers Series. Working Paper No. 3914. Available from internet: http://www.nber.org/papers/w3914.pdf ?new_window=1. https://doi.org/10.3386/w3914

Grundler, K., \& Scheuermeyer, P. (2014). Income Inequality, Economic Growth, and the Effect of Redistribution. P. 1-48. Available from internet: http://www.boeckler.de/pdf/v_2014_10_30_gr\%C3\%BCndler_scheuermeyer.pdf.

Gu, X., Dong, B., \& Huang, B. (2014). Inequality, Saving and Global Imbalances: A New Theory with Evidence from OECD and Asian Countries. The World Economy, 38(1), p. 110-135. Available from internet: http://onlinelibrary.wiley.com/doi/10.1111/twec.12188/full

Keynes, J. M. (1937). The General Theory of Employment. The Quarterly Journal of Economics, 51(2), p. $209-223$. https://doi.org/10.2307/1882087

Kilijoniene, A., Simanaviciene, Z., \& Simanavicius, A. (2010). The Evaluation of Social and Economic Development of the Region. Inzinerine Ekonomika-Engineering Economics(1), 68-79.

Kuijs, L., \& Wang, T. (2006). China's Pattern of Growth: Moving to Sustainability and Reducing Inequality. China \& World Economy, WPS3767, p. 13. Available from internet: https://core.ac.uk/download/pdf/6644989.pdf.

Lopez, R. (1994). The Environment as a Factor of Production: The Effects of Economic Growth and Trade Liberalization. Journal of Environmental Economics and Managements, No. 27. https://doi.org/10. 1006/jeem.1994.1032

Mahendra Dev, S. (2016). Economic Reforms, Poverty and Inequality. Indira Gandhi Institute of Development Research, WP-2016-009, p. 1-32. Available from internet: http://www.igidr.ac.in/pdf/publication/WP-2016-009.pdf.

Malinen, T. (2009). Estimating the long-run relationship between income inequality and economic development. Empirical Economics, Discussion paper, No. 260, p. 1-39. Available from internet: http://ethesis.helsinki.fi/ julkaisut/eri/hecer/disc/260/estimati.pdf.

Policardo, L. (2015). Democratisation, Environmental and Income Inequality. Environment and Development Economics, p. 1-30. Available from internet: http://www.harianregional.com/2016/01/masyarakatekonomi-asean-mea-menjadi.html

Rezai, A., \& Stagl, S. (2016). Ecological Macroeconomics: Introduction and Review. Ecological Economics, No. 9/Year 2, 1-13. https://doi.org/10.1016/j.ecolecon.2015.12.003

Ryoo, S. (2013). Demand-driven inequality, endogenous saving rate, and macroeconomic instability. Cambridge Journal of Economics, 40(1), 13.

Sbaouelgi, J., \& Boulila, G. (2016). Growth Differ among GCC Countries? Munich Personal RePEc Archive, 1-16. Available from internet: https://mpra.ub.uni-muenchen.de/70564/1/MPRA_paper_70564.pdf.

Schmidt-Hebbel, K., \& Serven, L. (2000). Does income inequality raise aggregate saving? Journal of Development Economics, 61, 417-446. https://doi.org/10.1016/S0304-3878(00)00063-8 
Scruggs, L. A. (1998). Political and economic inequality and the environment. Ecological Economics, 26, 259-275. https://doi.org/10.1016/S0921-8009(97)00118-3

Sineviciene, L., \& Vasiliauskaite, A. (2012). Fiscal Policy Interaction with Private Investment: the Case of the Baltic States. Inzinerine Ekonomika-Engineering Economics(3), 233-241. https://doi.org/10.5755/j01.ee.23.3.1934

Taylor, L., Rezai, A., \& Foley, D. K. (2015). An Integrated Approach to Climate Change, Income Distribution, Employment, and Economic Growth. Ecological Economics, 3/2015, 1-22.

Vona, F., \& Patriarca, F. (2011). Income Inequality and the Development of Environmental Technologies. Ecological Economics, 70(11), 2201-2213. https://doi.org/10.1016/j.ecolecon.2011.06.027

The article has been reviewed.

Received in January 2017; accepted in June 2017. 